Natalia KHOMA

Lwowski Uniwersytet Narodowy im. Iwana Franki, Ukraina

\title{
Symbolizm architektoniczny: polityka wyrażona $w$ kamieniu
}

\section{Architectural Symbolism: Politics Expressed in Stone}

\section{- Abstrakt •}

Przedmiotem studium jest architektura jako system znakowy, którego symbole mają znaczenie dla zrozumienia istoty i specyfiki polityki. Zbadano jak formy i obrazy architektoniczne w procesie percepcji wpływają na światopogląd polityczny. Obiekty architektoniczne analizowane są przez pryzmat semiotyki (jako znaki o podtekstach symbolicznych). Rzeczywistość polityczna przedstawiona została w jej znakowym odzwierciedleniu (wcielonym w architekturze).

Słowa kluczowe: architektura, znak polityczny, symbolizm polityczny, semiotyka polityki

\section{- Abstract •}

Architecture is studied as a system of signs symbols which are significant for understanding the essence and specific features of politics. We investigate how the architectural forms and images influence the political outlook of the person in the process of perception. Architectural objects are analysed through the sense of semiotics (as signs with some symbolic subtext). Political reality is presented in its symbolic (embodied in architecture) expression.

Keywords: architecture, political sigh, political symbolism, semiotics of politics

Architektura coraz częściej staje się obiektem analizy nauk socjo-humanistycznych i słusznie znajduje się w polu nauki o polityce. Architektura jest systemem znaków; jej symbole mają szczególne znaczenie dla zrozumienia istoty i specyfiki organizacji rzeczywistości politycznej. Celem studium jest ukazanie w jaki sposób formy oraz obrazy architektoniczne stają się środkami wpływu na światopogląd polityczny w procesie percepcji.

W ramach niniejszego badania rozpatrzymy obiekty architektoniczne w płaszczyźnie semiotycznej - jako znaki określające pewną właściwość polityczną, ozna- 
czające zjawisko polityczne, ujawniające treść i istotę struktur, w których zorganizowane jest życie polityczne. Nasze zadanie polega na przedstawieniu rzeczywistości politycznej w jej odzwierciedleniu znakowym (wcielonym w architekturze).

W budowlach architektonicznych umieszczane są podteksty symboliczne o charakterze politycznym. Architektura to zmaterializowana w formach monumentalnych informacja o czasie, społeczeństwie, procesach politycznych konkretnego okresu. Obiekty architektoniczne wszystkich czasów i wszystkich ludów można rozpatrywać jako elementy systemu znakowego polityki, fenomeny rzeczywistości stworzone rękami człowieka, które mają znaczenie polityczne. Elementy materialne oraz przestrzenne architektury są znakami-nośnikami informacji. System form architektonicznych jest środkiem komunikacji i posiada własne znaczenie semiotyczne (Ничкало, 2015); obiekt architektoniczny jest pewnym kanałem komunikacji (m.in. socjokulturowej, społeczno-politycznej), wiadomością w przestrzeni i czasie. Forma architektoniczna, która niesie znaczenie semantyczne, pełni funkcję komunikacyjną w procesie ludzkiej działalności, jest jednym ze sztucznych języków stworzonych przez człowieka. Powinna ona wyrażać treść artystyczną oraz przekazywać ją tym, dla kogo jest przeznaczona (Иконников, 1997).

Architektura jest narzędziem wyrazu nie tylko poziomu kultury społeczeństwa, lecz również dawnych lub istniejących tendencji w polityce, postaw wobec relacji między człowiekiem i władzą w systemie politycznym. Pośrednio charakteryzuje ona formę rządów, ustrój albo jest nośnikiem innych charakterystyk politycznych. Szczególne znaczenie dla poszukiwania symbolizmu politycznego $\mathrm{w}$ architekturze ma architektura reprezentacyjna (czyli budynki biurowo-administracyjne), ponieważ owe budynki „były i pozostają odzwierciedleniem treści i charakteru epoki oraz posiadają wyrazisty obraz siły i władzy” (Трошкіна, 2008, s. 91).

Symbolizm architektury należy badać jako składową semiotyki polityki, w granicach której polityka interpretowana jest jako system znakowy. Architekturę można rozpatrywać jako optyczny (wzrokowy) typ znaku politycznego. Zdaniem N. Juszynej „człowiek opracowuje dowolną informację znakową (wyrazy, cyfry, oznaczenia) i myśli za pomocą znaków. Znak to swoisty łącznik między rzeczywistymi i potencjalnymi znaczeniami wyrazu a tymi, którzy chcieliby pojąć te znaczenia" (2012, s. 329).

Chronologicznie pierwszymi obiektami przyciągającymi naszą uwagę badawczą z punktu widzenia znakowości, jest monumentalna architektura starożytnych cywilizacji wschodnich (np.: piramidy Starożytnego Egiptu, zigguraty babilońskie, grobowce chińskich imperatorów), która w formie symbolicznej odzwierciedliła zasady organizacji politycznej - władzę, kolektywizm, hierarchię itp. Ogromne kształty grobowców i świątyń carskich przekazywały idee potęgi pań- 
stwa, będąc ideologicznym osierdziem wspólnoty. Ich estetyka jest przede wszystkim estetyką władzy, wcieloną w prostych, ale również majestatycznych formach (Аанюк, 2015, s. 104-114). Ówczesne zabudowania pałacowe zadziwiały swoją potęgą, masywnością. Za pomocą środków architektoniczno-planistycznych kształtowano ceremonialne podejście do pałacu i jego centrum - sali tronowej będącej głównym elementem kompozycyjnym, tym podkreślano majestatyczność, siłę, nieugiętość władzy władcy (Трошкіна, 2008, s. 15). Co więcej, architektura o wymiarach piramid lub zikkuratów miała na celu stłumienie indywidualnej woli, wywołania u człowieka poczucia nikczemności w porównaniu z bezgraniczną potęgą państwa, wzbudzić zachwyt władzą u prostego człowieka.

Architektura starożytnych cywilizacji wschodnich była uosobieniem dwóch zasad: 1) zasady hierarchiczności władzy politycznej: władca wyższej rangi panował nad wszystkimi piętrami „piramidy” znajdującymi się pod nim; despotyczna władza przenikała w społeczeństwo, tworząc „piramidę społeczną”; 2) zasady kolektywizmu: upodobniając się do piramidy zbudowanej z milionów bloków kamiennych, „piramida polityczna” składała się z milionów indywiduów połączonych w całość; jej trwałość była możliwa tylko wtedy, gdy jej „bloki” - indywidua wspierały się wzajemnie i były „na miejscu”, czyli każdy pełnił złożone na nim funkcje socjalne.

Przeprowadzając paralelę między polityką a architekturą w starożytnym Egipcie, amerykański badacz J. Wilson pisał: „Przypisujemy Dżeserowi nie tylko początek monumentalnej architektury kamiennej w Egipcie, lecz również stworzenie nowego monstrum - biurokracji” (Гамалія, 2015). Państwo w epoce starożytnych cywilizacji wschodnich było więc podobne do „piramidy politycznej”, a ówczesna architektura monumentalna jest estetycznym symbolem władzy metafizycznej i państwa despotycznego.

W odróżnieniu od despotii wschodnich już w państwach antycznych główny akcent architektoniczny robiono nie na pałacu władcy, a na placu (agora w Republice Ateńskiej), forum (w Rzymie) jako miejscu zebrań publicznych. Jednocześnie, jeśli mowa nie o przestrzeni publicznej, lecz o architekturze reprezentacyjnej, to na przykład w Rzymie (w czasach Imperium) obserwujemy podobieństwo do architektury starożytnych despotii wschodnich. Rzym został ogarnięty wyobrażeniami o cesarzu jako o istocie boskiej; pod względem rozmachu pałace zbliżały się do pałaców despotów wschodnich (pałac Flawiuszy na Palatynie) i też charakteryzowały się podejściem ceremonialnym (Трошкіна, 2008, s. 16). Bogactwo pałaców Starożytnego Rzymu symbolizowało szacunek, potęgę oraz miało ładunek ideologiczny i programowy: nie zwykły pałac, lecz mieszkanie kosmicznego bóstwa (,złoty dom” Nerona). 
O ile państwo w epoce starożytnych cywilizacji wschodnich było podobne do „piramidy politycznej”, a w epoce antycznej - do „rzeźby politycznej”, to państwo średniowieczne możemy nazwać „świątynią polityczną”. W ramach religijnego światopoglądu średniowiecza estetyczno-symboliczne uosobienie maksymy politycznego bytu, zgodnie z którym „ciało” ziemskie państwa powinno zostać ograniczone przez element duchowy, wyraża średniowieczna sztuka sakralna, a w szczególności architektura gotycka. W świątyniach rozszerzano witraże, wypełniając wnętrze różnobarwnym światłem. Łukom i stropom nadawano kształt ostrołukowy symbolizujący promienie.

Dla człowieka średniowiecznego państwo było „świątynią” niebędącą dziełem rąk człowieka. W tym kontekście symbolem estetycznym chrześcijańskiego modelu budowy świata, a więc jego modelu społecznego - państwa, była sztuka średniowieczna (przede wszystkim architektura sakralna), pełniąca polityczne funkcje legitymacji władzy. Nie bez powodu wstępując na tron władcy średniowieczni, w tym książęta ukraińscy, wznosili świątynie symbolicznie oznaczające ich władzę (Аанюк, 2015, s. 108-112). Polityka średniowieczna nabywała wymiaru estetycznego upodobniając się do „świątyni”, a sztuka artykułowała podstawy światopoglądu władzy państwowej i była upolityczniona.

Taka sama izolacja, niedostępność, funkcyjność architektury, surowa prostota i ciężkość form była charakterystyczna również dla pałaców, jak też zamków średniowiecznych, szczególnie okresu romańskiego (XI-XII w.). W okresie gotyckim (XIII-XV w.) stopniowo tracą one wygląd twierdzy oraz przekształcają się w podmiejskie rezydencje, dwory dla wypoczynku, bez pomieszczeń dla sprawowania władzy i zgromadzeń dużej liczby urzędników. Sprzyjało temu powstanie nowego typu budynku użyteczności publicznej - ratusza (symbolu samorządu lokalnego), który zawsze był bardzo wysoki i posiadał wieżę jako symbol władzy. W ratuszach wykorzystywane były motywy architektury sakralnej: ostrość łuku, pionowość, zasada szkieletowości.

Znane przedstawicielskie budynki epoki renesansu (np. pałac Medici-Ricardi, pałac Piccolomini) miały formę sześcienną, co uosabia stabilność, nieugiętość, niezmienność i długowieczność władzy. Kształt kwadratu psychologicznie wywołuje poczucie trwałości oraz stabilności, w danym przypadku - władzy politycznej. Zwróćmy uwagę, że w systemie planistycznym epoki odrodzenia w centrum miasta znajdował się plac o znaczeniu publicznym, a w XVII-XVIII w. pojawiło się promieniowe (promienowo-okrężne, trójpromieniowe) planowanie ulic, gdy najważniejsze ulice schodzą się do głównego placu miasta.

W okresie absolutyzmu ogromne zespoły pałacowe symbolizowały potęgę królewską. Ludwik XIV (nazywany „królem Słońcem”), przekonany o boskim 
pochodzeniu władzy królewskiej, wcielił ideę własnego majestatu w zespole pałacowym - Wersalu. Promieniowy układ alej nie jest zwykłą metodą architektoniczną ukazującą wewnętrzne widoki w ogrodzie i widok na pałac, lecz pewnym znakiem chwały „króla Słońca”.

Można zauważyć, że nawet w najtrudniejszych czasach rozwoju państw starożytnych budynki reprezentacyjne wyróżniały się bogactwem na tle innych budowli, przejaw bogactwa jest bowiem demonstracją prestiżu, autorytetu, siły i władzy niezbędnych do ich tworzenia. Obecnie współistnieją dwie tendencje: 1) rozmach i luksus (np. pałace niepodległości w Astanie lub Mińsku); 2) brak zamiłowania do gigantomanii i pozornej rozkoszy, minimalizm i ekologiczność (np. rezydencja głowy państwa w Finlandii, premiera Japonii).

Zwracając się do architektury ukraińskiej, symbolizm polityczny w architekturze można przedstawić na przykładzie ukraińskiego (kozackiego) baroku. K. Tretiak argumentował, że architektura (zwłaszcza architektura kultowa) XVII-XVIII w. odzwierciedlała filozofię narodu, uosabiała ukraińską ideę narodową (Третяк, 2001, s. 40). Budynki (klasztory, świątynie) w stylu ukraińskiego baroku „oddychają" narodowym kolorytem, utożsamiają się ze wzrostem tożsamości narodowej i walką o własne państwo. Stawianie budowli barokowych było sposobem wyrażenia tożsamości Ukraińców, a zakaz budownictwa w tym stylu został odebrany jako akt zniesienia autonomii i asymilacji (Третяк, 2001, s. 41). Katarzyna II usilnie walczyła ze stylem architektonicznym baroku, narzucając imperatorski klasycyzm, który ignorował cechy narodowe $\mathrm{w}$ architekturze. Ten proces zakończył się w 1800 r., kiedy na mocy rozkazu Pawła I budownictwo cerkwi w stylu ukraińskim zostało oficjalnie zabronione (Огієнко, 1991, s. 14). Przez cały XIX w. ukraińskie świątynie barokowe były barbarzyńsko przebudowywane, zmieniały się ich typowe zarysy, żeby nadać im „bardziej rosyjski lub bizantyjski wygląd” (Майстренко, 1991, s. 46), ale pod koniec XIX w. zaczął się proces odrodzenia kultury tradycyjnej, „sobory i klasztory barokowe były postrzegane jako świadkowie tej sławnej przeszłości i jako protest przeciw koszarowemu klasycyzmowi, który miał na celu denacjonalizację kultury ukraińskiej” (Третяк, 2001, s. 41). O tym, że ukraińską architekturę XVII-XVIII w. utożsamiano z narodową tożsamością Ukraińców, uosobieniem walki Ukraińców o swoje prawa i niepodległość, świadczą również represje architektów, którzy tworzyli w stylu neobaroku w latach 30. XX w.

Odrębnym obiektem analizy jest architektura „totalitarna”. Totalitarna urbanistyka uwzględniała wszystkie potrzeby społeczeństwa industrialnego: miejsce chaotycznej zabudowy miała zająć surowa, zunifikowana i usystematyzowana architektura. Od olbrzymich gmachów w centrum stolic, stanowiących koncep- 
tualne i organizacyjne centrum społeczeństwa, szerokimi, prostymi promieniami rozchodziły się ulice, tworzące harmonijny, symetryczny układ.

Architektura totalitaryzmu pełniła jednak nie tylko funkcje propagandowe, lecz również społeczno-organizacyjne. Jej zadaniem była bowiem zmiana planowania przestrzeni i życia na niej z punktu widzenia relacji hierarchicznych: „władza - podporządkowanie”. Architektura stała się niejako estetyczno-przestrzenną „formą” polityki totalitarnej. Kluczowymi zadaniami tego planu były centralizacja społeczeństwa i organizacja jego połączeń systemowych (administracyjnych, transportowych i in.) na zasadzie „centrum - peryferie”.

Gigantomania, zaaprobowana jeszcze w czasach starożytnych despotii wschodnich, w pełni przejawiła się w nowożytnych reżimach totalitarnych. Gigantomania w ogóle była charakterystyczna dla totalitaryzmu - rozmiar budowli miał tłumić indywidualną wolę, wywoływać drżenie przed władzą. W szczególności A. Hitler i J. Stalin mieli zamiar zmienić planowanie (umieścić w centrum megabudowle) odpowiednio Berlina i Moskwy, żeby upodobnić je do stolic światowych imperiów:

- „Sala Narodu” („Sala Chwały”) w Berlinie miała mieścić 180 tys. osób, 17 razy przekraczając rozmiar bazyliki Św. Piotra w Rzymie; jego kopułę miał wieńczyć orzeł germański trzymający w szponach kulę ziemską;

- granitowy „Pałac Rad” w stylu „klasycyzmu stalinowskiego” w Moskwie miał symbolizować potencjał socjalizmu; gmach miał zostać najwyższą ówczesną budowlą świata (wysokość 420 m według końcowego projektu); budowa ruszyła na miejscu zburzonej cerkwi Chrystusa Zbawiciela, czemu również nadano symboliczny podtekst. Przewidywano, że po nieuniknionym zwycięstwie komunizmu na całym świecie gmach będzie jego siedzibą. Odpowiednio dla takiej bardzo ważnej roli gmach powinien być najwyższy oraz być uwieńczony największym monumentem (Lenina) na świecie;

- Pałac cywilizacji włoskiej w Rzymie stał się symbolem epoki B. Mussoliniego. Architektura pałacowa miała z rozmachem wcielić w kamieniu ideę „nowego Imperium Rzymskiego”, demonstrowała pragnienie transformacji form historycznych, czyniąc je bardziej potężnymi i nowoczesnymi. Przed architekturą stawiano zadanie stworzenia atmosfery masowego uniesienia poprzez kształtowanie „wielkiego stylu” - nadludzka skala, zamiana wyczucia miary na wyczucie bezmiaru, aby człowiek poczuł, iż jest związany z wielką sprawą i ogromną wspólnotą (Помьщикова, Сафонов, 2013, s. 148). Uczyniono ideologiczne ukierunkowanie na surowy ascetyzm, sławienie pracy, urodzaju. 
Tak ogromne oraz nadzwyczajnie wysokie megabudowle miały stanowić świadectwo potęgi mocarstw totalitarnych, ich wyższości nad innymi narodami. Reżimy totalitarne zawsze boleśnie martwią się o to, by uznał je cały świat, zaś architekturę traktują jako wzmocnienie renomy międzynarodowej, demonstrację pewnej wzorowości, jak rzucona w $1971 \mathrm{r}$. przez L. Breżniewa idea „wzorowego miasta komunistycznego” (co do Moskwy, która miała stać się „witryną” socjalizmu).

Jeśli popatrzeć na planowanie stolic współczesnych demokracji (Waszyngton, Canberra, Wiedeń, Paryż, Praga, Berlin, Rzym i in.), to ich podstawą jest kompozycja wieloogniskowa: centra władzy ustawodawczej, wykonawczej i sądowej są rozrzucone terytorialnie, symbolizując decentralizację władzy. Polityczne centra państwa (architektura reprezentacyjna - budynki parlamentu, rządu i sądu najwyższego) zazwyczaj połączone są kilkoma głównymi magistralami miasta. Ponadto w strukturze miasta stołecznego wyraźnie wyróżniają się centra ogólnopaństwowego, regionalnego i lokalnego poziomu zarządzania. Podział władzy w planowaniu architektonicznym najwyraźniejszy jest w Waszyngtonie oraz Canberze.

Centrum polityczne Wiednia, Pragi, Bratysławy zbudowane jest w kształcie koła. Budynki władzy ustawodawczej zazwyczaj usytuowane są w dzielnicach najbardziej atrakcyjnych. Niby podążając za wybitnym Jean-Jacques Rousseau wraz z jego teorią o tym, że podstawą i sercem państwa jest władza ustawodawcza, takie pozycje zajmują budynki parlamentów Londynu, Budapesztu, Berlina i in. W Paryżu wszystkie powojenne obiekty ogólnopaństwowe budowane są wzdłuż osi „Zachód-Wschód”.

Zadania architektury dawnych czasów i XXI wieku są zupełnie inne: jeśli, na przykład, w trzecim tysiącleciu przed naszą erą (państwa starożytne) architektura była wykorzystywana do akcentowania majestatu władców i nikczemności prostych ludzi, to w trzecim tysiącleciu naszej ery architektura ukierunkowana jest na jak najszerszą inkluzję społeczną (zaangażowanie), stworzenie nowych możliwości dla współdziałania ludności. Wykrystalizowuje się również tendencja do połączenia w granicach jednego budynku lub dzielnicy jak największej ilości instytucji ogólnopaństwowych lub municypalnych w celu optymalizacji procesu zarządzania. Na przykład od 2007 r. w Korei Południowej budowane jest nowe miasto Sedżong w centralnej części kraju, gdzie będą zwarcie rozlokowane wszystkie instytucje państwowe i miejsca zamieszkania pracowników w pobliżu miejsc pracy. Albo też stolica Brazylii, Brasilia była zbudowana w celu wyniesienia struktur państwowych poza granice historycznych miast Rio de Janeiro, São Paulo i Salvador. Specjalne kwartały rządowe są cechą charakterystyczną Chandigahr (Indie), Oslo (Norwegia), Kuala Lumpur (Malezja) i wielu miast. 
Wśród badaczy procesów modernizacji współczesnej architektury występują polarne opinie dotyczące sensów nadawanych powyższemu przeformatowaniu; jedni twierdzą, że obraz nadal pozostaje główną siłą architektury, a inni akcentują, że forma architektoniczna sama w sobie stopniowo traci znaczenie, ustępując wzrastaniu roli przeznaczenia obiektu i jego funkcjonalności dla komunikacji społecznej. Oczywiście często współczesne formy architektoniczne zaskakują swoją niezwykłością. Jednak obecnie coraz częściej forma uwarunkowana jest potrzebami społecznymi. Współczesna architektura potrafi identyfikować dzielnice, tworzyć nową, atrakcyjną przestrzeń społeczną. Niezwykłe budynki, place, parki sprzyjają komunikacji międzyludzkiej i transformują świadomość mieszkańców, zmieniając jakość przestrzeni miejskiej. Współcześni architekci o orientacji demokratycznej współpracują z władzą, żeby zaproponować pewne strategie dla polepszenia życia wspólnoty.

Współczesne politologiczne badania naukowe w dziedzinie symbolizmu architektonicznego aktualizują się wzrostem znaczenia urbanistyki politycznej i koniecznością dalszego, pogłębionego badania polityki jako systemu znakowego.

\section{Bibliografia:}

Гамалія, К. (2015). Монументи вічності: піраміди Аавнього Єгипту. Pobrane z: http://www.stattionline.org.ua/iskystvo/97/16807-monumenti-vichnosti-piramididavnogoyegiptu.html.

Иконников, А. (1997). Историзм в архитектуре. Москва: Стройиздат.

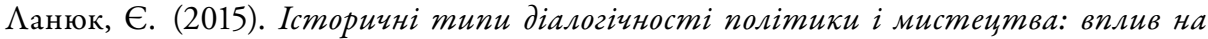

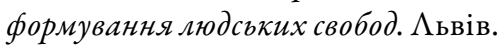

Майстренко, $\Lambda$. (1991). Ао проблеми вивчення архітектури Гетьманщини XVIIXVIII ст. Архітектура Украӥни 5.

Ничкало, С.А. (2013). Мистещтво архітектури: виховний потенщіал. Pobrane z: http://lib.iitta.gov.ua/5487/1/Nychkalo_2013\%D1\%81.pdf.

Огієнко, I. (1991). Українська культура. Київ: Абрис.

Польщикова, Н., Сафонов, Е. (2013). Архитектура тоталитаризма в европейских странах (1933-1945 гг.). Проблемь теории и истории архитектуры Украины 13.

Третяк, К. (2001). Українське барокко як вираз національної ідеї в архітектурі. Етнічна історія народів Європи 9.

Трошкіна, О. (2008). Семантика архітектури. Київ.

Трошкіна, О. (2008). Семантичні основи представницької архітектури. Вісник Харківської державної академії дизайну імистеитв 13.

Юшина, Н. (2012). Теорія знаків як метод АосліАження політичного образу. Вісник Аввівського університету, Серія „Філософсько-політологічні студї” 1 . 